\title{
Pattern Reconfigurable Patch Antenna menggunakan Edge Shorting Pin dan Symmetrical Control Pin
}

\author{
DWI ANDI NURMANTRIS ${ }^{1}$, HEROE WIJANTO ${ }^{2}$, BAMBANG SETIA NUGROHO²
}

\author{
1. Fakultas Ilmu Terapan, Telkom University \\ 2. Fakultas Teknik Elektro, Telkom University
}

Email : dwiandi@tass.telkomuniversity.ac.id

\begin{abstract}
ABSTRAK
Metode baru dalam mendesain suatu pattern reconfigurable antenna telah diteliti. Penelitian ini fokus pada optimasi antena patch lingkaran single layer pencatuan probe koaksial dengan mengintegrasikan 24 switch/shorting pin pada sisi patch yang disebut edge shorting pin dan 8 shorting pin membentuk lingkaran dengan radius tertentu dan selanjutnya disebut symmetrical control pin yang fungsinya sebagai metode penyepadan impedansi. Algoritma Genetika yang dikombinasikan dengan Finite Element Software digunakan untuk mengoptimasi kombinasi switch, radius lingkaran symmetrical control pin, dan radius patch untuk mendapatkan kemampuan pattern reconfigurability. Antena ini menghasilkan 8 kemungkinan arah radiasi azzimuth dengan resolusi $45^{\circ}$ dan arah elevasi $30^{\circ}$ pada frekuensi 2,4 Ghz. Optimasi, simulasi, fabrikasi, dan pengukuran dilakukan untuk memverifikasi hasil penelitian.
\end{abstract}

Kata kunci: Patch Lingkaran, Edge Shorting Pin, Symmetrical Control Pin, Algoritma Genetika, Pattern Reconfigurable

\begin{abstract}
New method for desaining pattern reconfigurable antenna was studied. This study focuses on the optimization of a single layer circular patch antenna with probe feed by integrating the 24 switch / shorting pin on the side of the patch that called Edge Shorting Pins and 8 shorting pins form circular line in such radius that called Symmetrical Control Pins as a impedance matching method. Genetic algorithm combined with the Finite Element Software is used to optimize the switch combination, the radius of circular line of symmetrical control pins, and the patch radius to obtain a pattern reconfigurability capabilities. This antenna produces 8 possible directions of azimuth radiation with a resolution of $45^{\circ}$ and $30^{\circ}$ elevation direction at a frequency of $2.4 \mathrm{GHz}$. Optimization, simulation, fabrication, and measurement was done to verify the results.
\end{abstract}

Keywords: Circular Patch, Edge Shorting Pin, Symmetrical Control Pin, Genetic Algorithm, Pattern Reconfigurable 
Nurmantris, dkk

\section{PENDAHULUAN}

Reconfigurable antenna menjadi popular beberapa tahun terakhir karena kelebihannya yang mampu direkonfigurasi karakteristik medan dekatnya seperti frekuensi kerja maupun karakteristik medan jauhnya seperti pola radiasi dan polarisasi dengan tetap mempertahankan ukuran dimensi fisiknya sehingga secara sistem akan lebih cocok digunakan pada perangkat-perangkat yang kecil dan portable (Zhang dkk. 2008).

Kemampuan pattern reconfigurability pada antena planar biasanya dapat dicapai dengan menggunakan switch RF seperti PIN Diode dan RF MEMs dimana kombinasi state "on" dan "off" pada switch-switch yang terintegrasi pada elemen antena bisa mengubah distribusi arus pada struktur antena sehingga karakteristik pancaran antena tersebut bisa berubah (Zhang dkk. 2008).

Beberapa peneliti sudah memaparkan beberapa design pattern reconfigurable antenna menggunakan switch RF. Kemampuan pattern reconfigurable didapat dengan memilih struktur radiator yang tidak sederhana seperti bentuk spiral sehingga sangat berpeluang untuk membuat pattern reconfigurable (C. Jung dkk.2005), (Huff dkk. 2003), (Huff dkk. 2004), (Huff dkk. 2006). Dua arah pancaran dari antena tunggal bisa di switch untuk merubah arah pancaran, yaitu pancaran conical ke pancaran broadside (Chen dkk. 2007). Single antena stacked patch bisa menghasilkan pattern reconfigurable sekaligus frequency reconfigurable (Ali dkk. 2007). Kesamaan karakteristik dari pattern reconfigurable antenna diatas adalah terbatasnya derajat pattern reconfigurable nya.

Algoritma genetika (AG) merupakan teknik optimasi global yang terinspirasi dari teori Darwin yaitu teori seleksi dan evolusi. Dalam bidang elektromagnetika, AG sudah berhasil digunakan tidak hanya untuk optimasi antena saja tetapi bahkan dapat menemukan varian-varian baru struktur antena. Awalnya, dalam bidang optimasi antena, AG sering digunakan untuk optimasi antenna susun (Ares. 1999). AG juga digunakan untuk mendesain dan mengoptimasi wire antenna (Linden. 1997). AG juga berhasil digunakan untuk mengoptimasi struktur antena untuk mendapatkan bandwidth yang lebih lebar (Choo dkk. 2000) dan multiband (Choo dkk. 2002),(Ozgun,2003). AG juga berhasil digunakan untuk tujuan mengecilkan radiator pada patch antenna (Herscovici dkk. 2001). Dalam reconfigurable antenna, AG juga digunakan oleh lopez (Lopez. 2010)

Shorting Pin adalah suatu konduktor dengan radius kecil yang menghubungkan antara patch dengan groundplane. Pengintegrasian shorting pin pada antena untuk dimanfaatkan sebagai pattern reconfigurable mechanism masih belum banyak digunakan karena pola perubahan medan yang disebabkan oleh shorting sangat kompleks dan penelitian yang memfokuskan pada area ini masih sedikit. Tetapi, efek shorting pada frekuensi resonansi sudah dimulai sejak awal tahun 90-an meskipun setiap analisa yang dilakukan masih terbatas pada kasuskasus yang masih terbatas. Penjelasan secara sederhana mengenai efek shorting terhadap frekuensi resonansi bisa dijelaskan melalui pendekatan saluran transmisi, dimana ketika beberapa shorting ditambahkan pada antena mikrostrip maka induktansi L seri maupun kapasitansi C paralel muncul pada rangkaian ekuivalennya. Induktansi L muncul merepresentasikan self inductance dari shorting pin sedangkan kapasitansi C muncul merepresentasikan close proximity antar shorting pin (Ramesh dkk. 2001). Jika hanya ada 
dua buah shorting pin yang diintegrasikan, maka efek dari shorting pin tersebut mirip seperti saluran dua kawat kembar yang nilai induktansi dan kapasitansinya bisa dituliskan sebagai berikut :

$$
\begin{aligned}
& L=\left(t^{\mu} / \pi\right) \cosh ^{-1}(d / 2 a) \\
& C=\frac{t \pi \varepsilon}{\cosh ^{-1}(d / 2 a)}
\end{aligned}
$$

dimana $\mathrm{t}$ adalah ketebalan substrat, a adalah radius shorting pin, d adalah jarak antar shorting pin, dan masing -masing adalah permeabilitas dan permitivitas bahan substrat.

Pada penelitian ini, telah dilakukan simulasi, optimasi, dan fabrikasi antena patch sederhana berbentuk lingkaran dengan edge shorting pin dan symmetrical control pin dengan fokus penelitian pada optimasi pengarahan pola radiasi antena. Algoritma optimasi menggunakan AG dengan bantuan Finite Element Method (FEM). AG diimplementasikan pada matlab dan FEM dilakukan dengan software Ansoft HFSS, dimana integrasi keduanya memungkinkan dengan bantuan scripting HFSS dengan bahasa Visual Basic (VBScript). Tantangan utama pada penelitian ini adalah mengoptimasi karakteristik pola radiasi antena untuk mendapatkan kemampuan pattern reconfigurable dengan derajat yang tinggi dengan tetap mempertahankan karakteristik frekuensi resonansi antena.

\section{STRUKTUR ANTENA}

Desain antena yang diteliti merupakan antena patch lingkaran dengan menambahkan 8 shorting pin yang posisinya simetris diletakkan di area patch membentuk garis lingkaran dengan radius tertentu yang selanjutnya disebut symmetrical control pin. Fungsi utama control pin ini adalah untuk matching impedance. Dengan penambahan symmetrical control pin ini, metoda pencatuan probe feed bisa dipertahankan di pusat patch sedangkan teknik penyepadan impedansinya bisa dilakukan dengan mengatur radius garis lingkaran dari symmetrical control pin. Frekuensi resonansi antena ini sangat dipengaruhi oleh radius dalam patch nya. Karakteristik dan analisis antena patch lingkaran dengan symmetrical control pin bisa dilihat pada referensi (Ravipati dkk. 2005). 


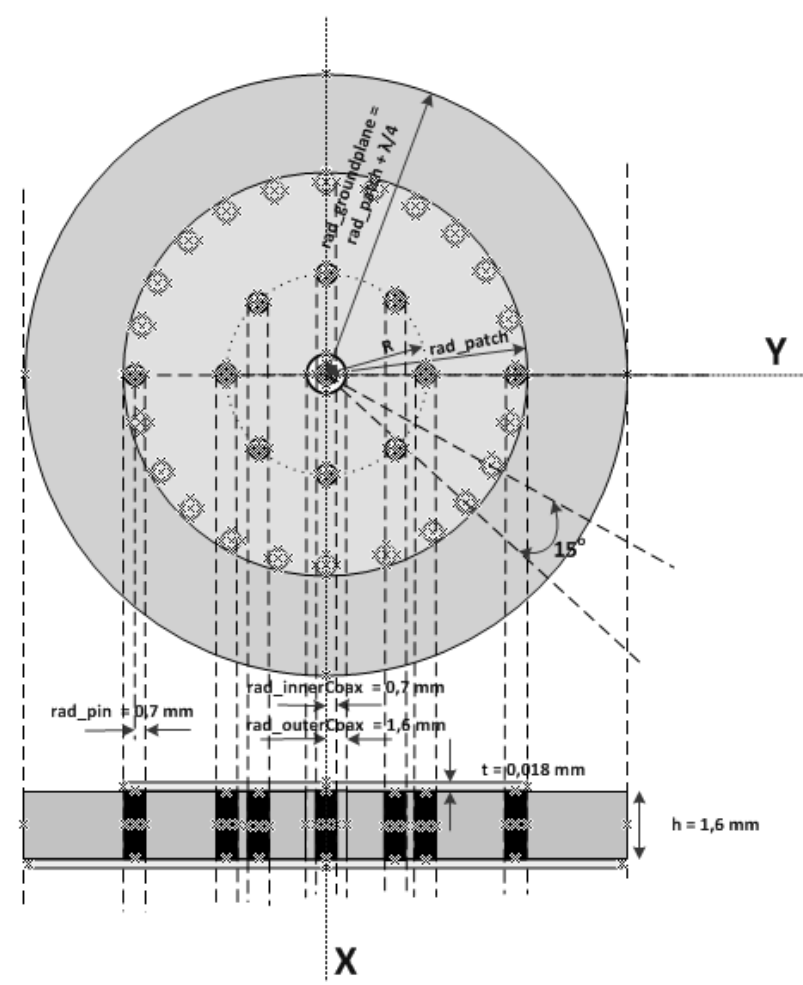

\section{Gambar 1. Struktur Antena Patch Lingkaran dengan edge shorting pin dan symmetrical} control pin

Pada tepi patch, 24 swith diintegrasikan pada antena. Switch kondisi "ON" direpresentasikan dengan adanya shorting pin sedangkan switch kondisi "OFF" direpresentasikan dengan tidak adanya shorting pin. Antena didesain dengan bahan substrat Epoxy FR4 dengan $\varepsilon_{r}=4,4$. Struktur antena patch lingkaran dengan symmetrical control pin yang telah diintegrasikan dengan edge shorting pin bisa dilihat pada Gambar 1. Nilai-nilai awal parameter lengkap antena bisa dilihat pada Tabel 1 .

Tabel 1. Nilai Awal Parameter-parameter Antena Patch Lingkaran dengan edge shorting pin dan symmetrical control pin

\begin{tabular}{|l|l|l|}
\hline Parameter & Simbol & Nilai \\
\hline Radius patch & rad_patch & Akan dioptimasi \\
\hline Radius garis lingkaran symmetrical control pin & R & Akan dioptimasi \\
\hline Tebal konduktor & t & $0,018 \mathrm{~mm}$ \\
\hline Tebal substrat & h & $1,6 \mathrm{~mm}$ \\
\hline Radius inner (probe) koaksial & rad_innerCoax & $0,7 \mathrm{~mm}$ \\
\hline Radius outer koaksial & rad_outerCoax & $1,6 \mathrm{~mm}$ \\
\hline
\end{tabular}

Parameter antenna : radius patch, radius garis lingkaran symmetrical control pin, dan kombinasi switch (edge shorting pin) akan dioptimasi. 


\section{PROSEDUR OPTIMASI}

\subsection{Prosedur Secara Umum}

Dalam penelitian ini tujuan utama dari optimisasi adalah untuk mencari konfigurasi kombinasi switch pada struktur antena yang menghasilkan polaradiasi antena yang sudah di state di awal. Dalam desain optimasi ini, sudut elevasi $45^{\circ}$ dijadikan target seperti diilustrasikan pada Gambar 2. untuk dicapai yang tentu saja tetap mempertahankan kondisi matching impedansi di titik terminal pada frekuensi yang diinginkan. Untuk itu variablevariable yang lain, selain kombinasi switch, yaitu radius garis melingkar dari symmetrical control pin untuk mengontrol matching impedance dan radius patch untuk mengontrol frekuensi resonansi perlu dioptimasi juga.

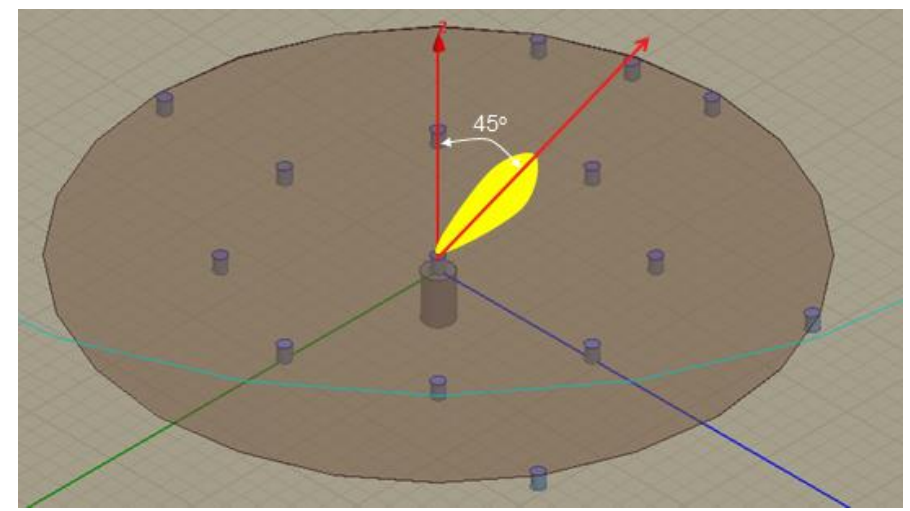

Gambar 2. Ilustrasi Pola pancar Antena Target

Saat hasil optimum ditemukan maka akan didapatkan sebuah desain pattern reconfigurable antenna, dimana kemampuan reconfigurability didapat dengan memutar kombinasi switch yang sudah didapatkan pada proses optimasi sehingga kemudian pola radiasi antena bisa diputar secara azimut sebesar $360^{\circ}$ dengan derajat reconfigurability tiap putaran beam tergantung dari jumlah symmetrical control pin yang digunakan, karena struktur antena yang simetris.

Prinsip kerja Algoritma genetika sebenarnya didasarkan pada teori evolusi Darwin. Dalam kasus optimasi kombinasi switch pada antena untuk pattern reconfigurable ini, mula-mula diambil beberapa set kombinasi switch (populasi), yang disebut generasi 1 , tiap set direpresentasikan dengan kumpulan bit biner (kromosom) sebanyak jumlah switch yang dipakai ditambah jumlah bit yang mengkodekan variable-variable lain selain kombinasi switch. Sebagai contoh, variable radius patch dikodekan dengan 10 bit. Pemilihan jumlah bit biner sebanyak 10 bit untuk mengkodekan nilai variable antena didasarkan untuk merepresentasikan solusi yang kontinu sehingga semakin banyak jumlah bit yang digunakan, maka akurasinya juga semakin tinggi, meskipun ketelitian fabrikasi menjadi batasannya. Pada variable kombinasi switch, bit ' 0 ' merepresentasikan kondisi switch 'off' (tidak ada shorting pin) dan bit '1' merepresentasikan kondisi switch 'on' (ada shorting pin). Ilustrasi pengkodean variable antena pada struktur antena untuk algoritma genetika dapat dilihat pada Gambar 3 Kemudian tiap-tiap kromosom dievaluasi fungsi fitnesnya, jika dalam satu generasi belum ada yang memenuhi kriteria, maka dengan operasi pada GA akan dipilih individu yang memiliki nilai fitnes yang tertinggi untuk dipilih sebagai orang tua (parent). Kemudian dengan menggabungkan (cross over) bagian kromosom dari 2 buah orang tua dan sedikit memodifikasi (mutasi) dari kromosom tiap individu, generasi baru dibuat, dan disebut generasi 2. Kemudian generasi kedua ini di evaluasi kembali. Proses ini diulang 
kembali hingga seterusnya hingga kriteria terpenuhi atau sampai jumlah generasi yang dibangkitkan selesai dievaluasi dan didapat solusi optimum.

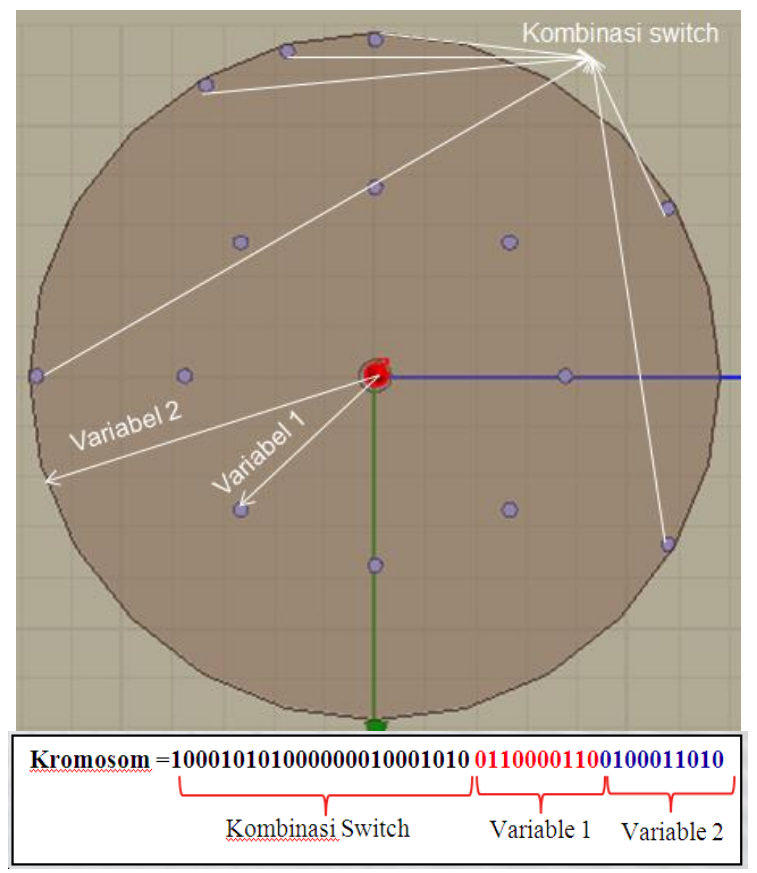

\section{Gambar 3. Ilustrasi Kromosom (AG) pada struktur antena}

Fungsi fitnes merupakan nilai kuantitatif yang merepresentasikan performansi dari antena untuk satu set kromosom. Semakin tinggi nilai fitness maka antena tersebut semakin mendekati spesifikasi antena yang diinginkan. Dalam menentukan fungsi fitnes sebenarnya ada beberapa pilihan cara, dalam hal ini penulis menggunakan fungsi fitnes berikut :

$$
\text { Fitness }=4 \times \text { Directivit } \mathrm{y}(\theta, \phi)+\left|\mathrm{S}_{11(\mathrm{~dB})}(\mathrm{f})\right|
$$

Fungsi fitnes ini akan memaksimalkan pola pancar antena kearah tertentu dan sekaligus meminimalkan pantulan (mismatch loss) pada frekuensi resonansi.

\subsection{Blok Diagram FEM/AG}

Blok Diagram Optimizer menggunakan AG/FEM bisa dilihat pada Gambar 4.

\section{Initiation}

Pada bagian ini, permasalahan optimasi diinisialisasi. Permasalahan utama pada optimasi antena diterjemahkan dalam lingkungan AG. Pada bagian ini juga sebuah populasi yang terdiri dari beberapa individu dibangkitkan dan di seleksi berdasarkan nilai fitnesnya.

\section{Reproduction Cicle}

Pada bagian ini proses-proses AG dijalankan seperti, seleksi orang tua, pindah silang, dan mutasi. Proses-proses ini yang akan menjadi cikal bakal terbentuknya generasi baru.

\section{Population Generation}

Pada bagian ini, seluruh individu dalam populasi pada generasi tertentu diganti dengan generasi baru kemudian di hitung kembali nilai fitnesnya. 


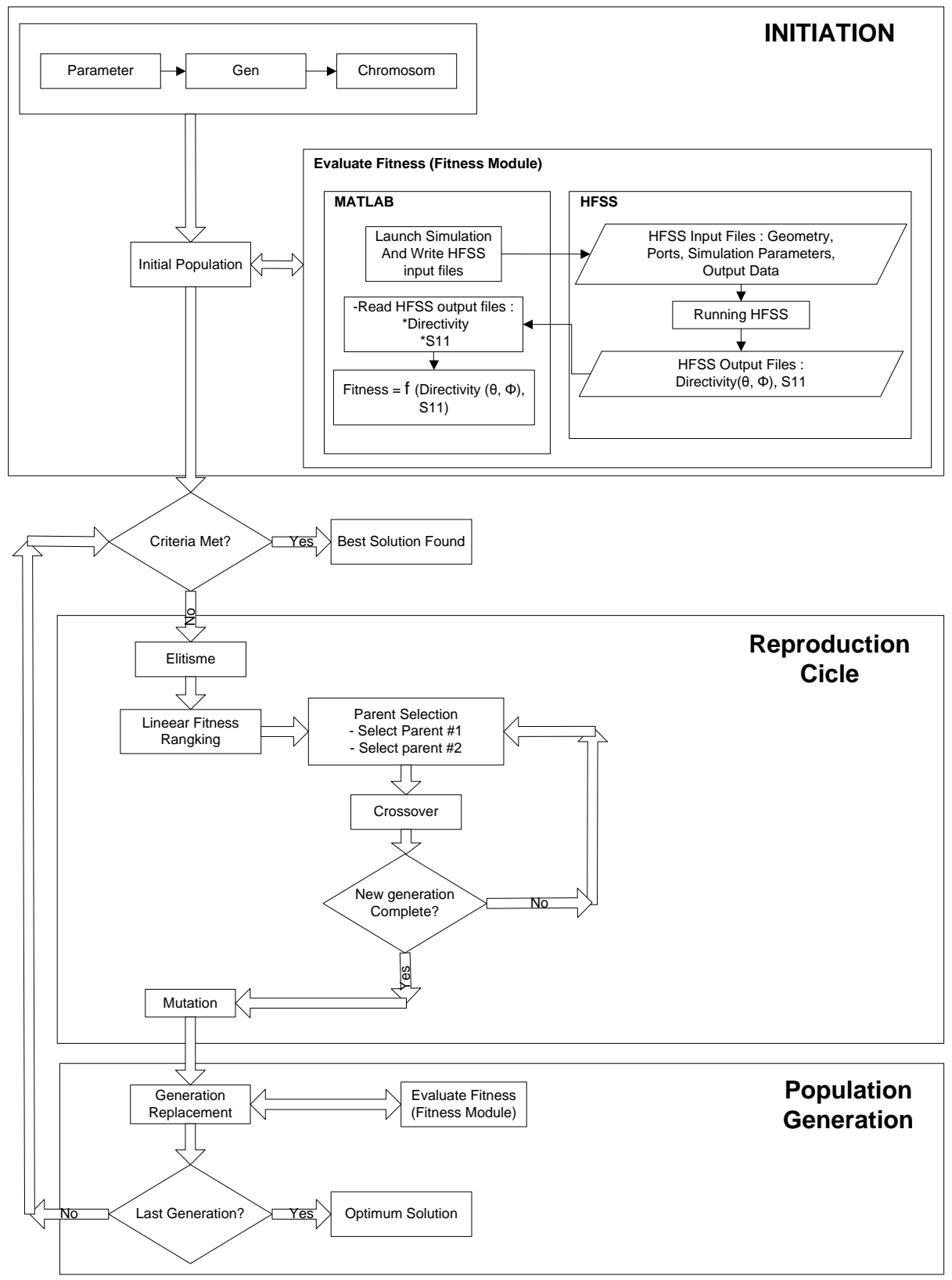

Gambar 4. Diagram Blok FEM/AG

\subsection{AG Parameter Setup}

Ada tiga parameter AG yang paling penting dan sangat mempengaruhi hasil dari optimasi. Parameter tersebut adalah ukuran populasi, probabilitas crossover, dan probabilitas mutasi. Ukuran populasi yang terlalu sedikit akan membuat variasi pada kromosom tiap generasi sangat rendah sehingga akan cepat konvergen, tapi ukuran populasi yang terlalu besar juga membuat komputasi makin lama. Biasanya ukuran populasi berkisar 30 sampai 1000 . Pada penelitian ini ukuran populasi dipilih sebesar 32

Untuk nilai probabilitas crossover biasanya berkisar antara 0,6 sampai 0,9 dan pada penelitian ini digunakan probabilitas crossover sebesar 0,875 . Sedangkan untuk probabilitas mutasi biasanya kecil berkisar antara 0,001 sampai 0,01 dan dalam penelitian ini digunakan probabilitas mutasi sebesar 0,01 . Ringkasan parameter setup AG pada pattern reconfigurable antenna bisa dilihat pada Tabel 2 . 
Tabel 2. AG Parameter Setup pada Pattern Reconfigurable Antenna

\begin{tabular}{|l|l|}
\hline \multicolumn{1}{|c|}{ ISTILAH } & \multicolumn{1}{c|}{ Keterangan dan Setup } \\
\hline Population & $\begin{array}{l}\text { Sekumpulan nilai-nilai variable antena seperti kombinasi switch, radius patch, dan } \\
\text { variable pengontrol matching impedance yang nilainya akan dioptimasi dengan } \\
\text { algoritma genetika. Ukuran Populasi }=32\end{array}$ \\
\hline Chromosome & $\begin{array}{l}\text { Satu nilai variable antena seperti satu kemungkinan kombinasi } \text { switch, satu nilai } \\
\text { radius patch, dan satu nilai lebar slit yang telah dikodekan. Satu kromosom }=44 \\
\text { bit }\end{array}$ \\
\hline Gen & $\begin{array}{l}\text { Satu nilai variable antena yang telah dikodekan misalnya gen 1 : radius patch (10 } \\
\text { bit), gen2 : kombinasi switch (24 bit), gen 3: lebar slot (10 bit) }\end{array}$ \\
\hline Parent & - \\
\hline Offspring & - \\
\hline Crossover & One -point Crossover dengan Pc $=0,875$ \\
\hline Mutation & Mutasi dimungkinkan terjadi pada seluruh bit dalam kromosom dengan Pm $=0,01$ \\
\hline $\begin{array}{l}\text { Selection } \\
\text { Procedure }\end{array}$ & Roulette Wheel Selection \\
\hline $\begin{array}{l}\text { Evaluation } \\
\text { Function }\end{array}$ & Fitness $=4 \times$ Directivit $y(\theta, \phi)+\mid \mathrm{S}_{11(\mathrm{~dB})}(\mathrm{f})$ \\
\hline Generation & $\begin{array}{l}\text { Satu populasi yang telah dievaluasi nilai fitnessnya serta mengalami CrossOver } \\
\text { dan mutasi disebut generasi ke-N. Maksimum Generasi }=10\end{array}$ \\
\hline
\end{tabular}

\section{HASIL OPTIMASI DAN VALIDASI}

Hasil simulasi optimum tercapai saat nilai fitness mencapai 34,38 pada iterasi ke-5 (generasi 5) setelah generasi tersebut, tidak ada lagi perbaikan fitness seperti terlihat pada Gambar 5 Sedangkan nilai-nilai variable optimum bisa dilihat pada Tabel 3

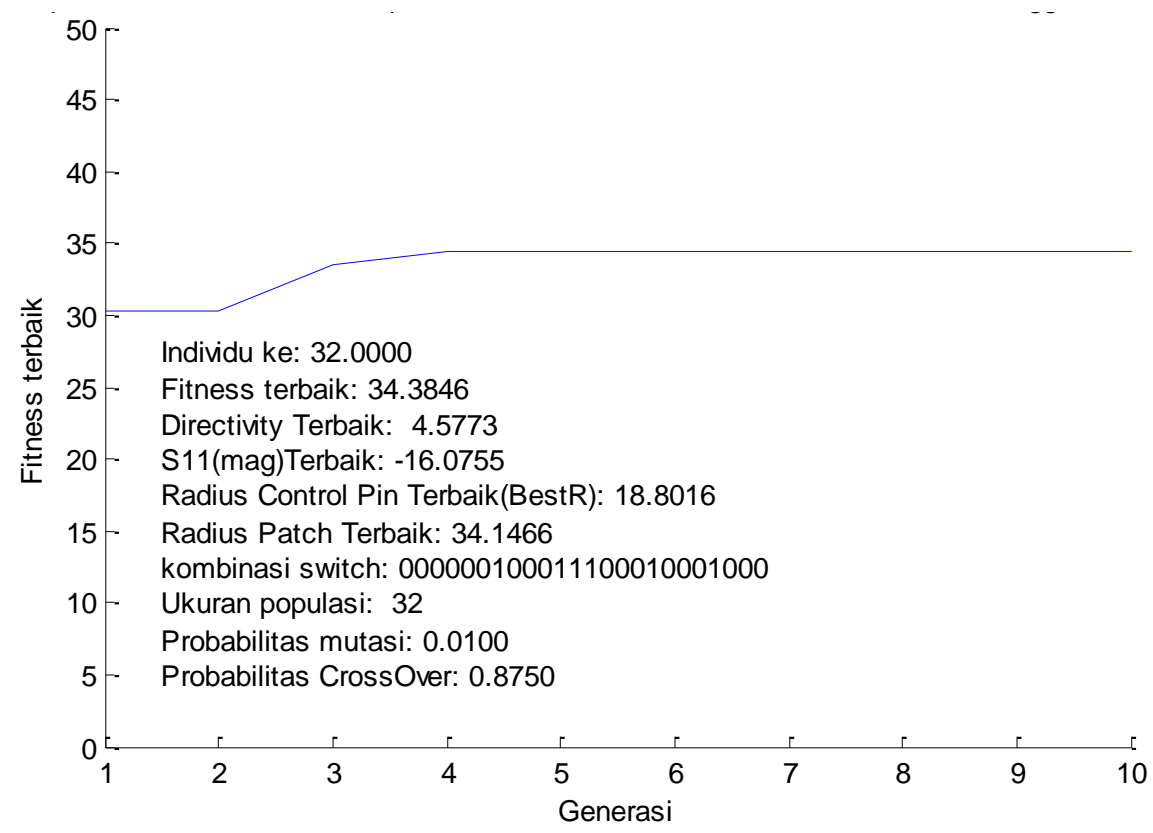

Gambar 5. Hasil simulasi optimasi FEM/AG pada Antena patch Lingkaran dengan edge shorting pin dan symmetrical control pin. 
Optimasi Kombinasi Switch Pada Pattern Reconfigurable Circular Patch Antenna Menggunakan Edge Shorting Pin Dan Symmetrical Control Pin

Tabel 3. Nilai variable optimum pada Antena Patch Lingkaran edge shorting pin dan symmetrical control pin.

\begin{tabular}{|l|l|}
\hline Variable & Nilai Optimum \\
\hline Rad_patch & 34.1466275659824 \\
\hline R & 18.8015640273705 \\
\hline Kombinasi Switch & 000000100011100010001000 \\
\hline
\end{tabular}

Karakteristik antena menggunakan variable-variable optimum bisa dilihat pada Gambar 6 . Dari gambar tersebut terlihat bahwa pola radiasi antena unidirectional dengan main beam mengarah pada sudut elevasi $30^{\circ}$, sedangkan frekuensi resonansi pada frekuensi $2,385 \mathrm{Ghz}$ dengan return loss minimum sebesar $-36,65 \mathrm{~dB}$, directivity maksimum $6 \mathrm{~dB}$ dan bandwidth sebesar $56,3 \mathrm{Mhz}$ atau 2,36\%

Karakteristik ini adalah hasil maksimum yang mendekati spesifikasi awal antena. Perubahan pola radiasi arah azimuth didapat dengan memutar kombinasi switch sejauh $360^{\circ}$. Hasil pola pancar antena dari 8 state (state $1 \mathrm{~s} / \mathrm{d}$ state 8 ) bisa dilihat pada tabel 4 . Sedangkan perubahan return lossnya bisa dilihat pada Gambar 8. Dari gambar tersebut terlihat bahwa perubahan-perubahan state hanya merubah pola pancar antena sedangkan return loss nya tetap.

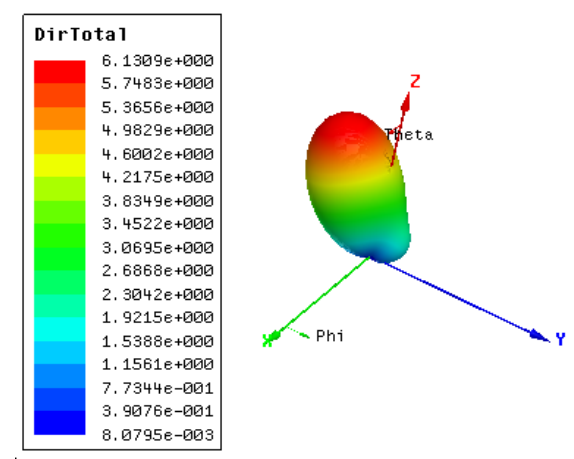

(a)

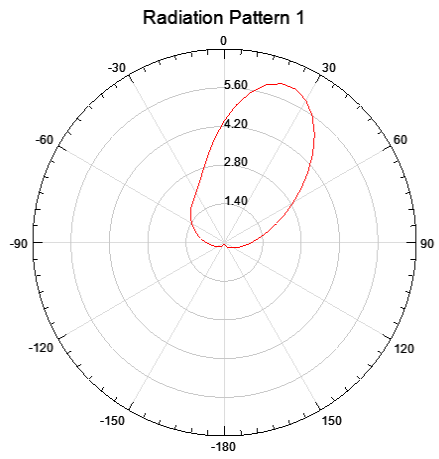

(b)

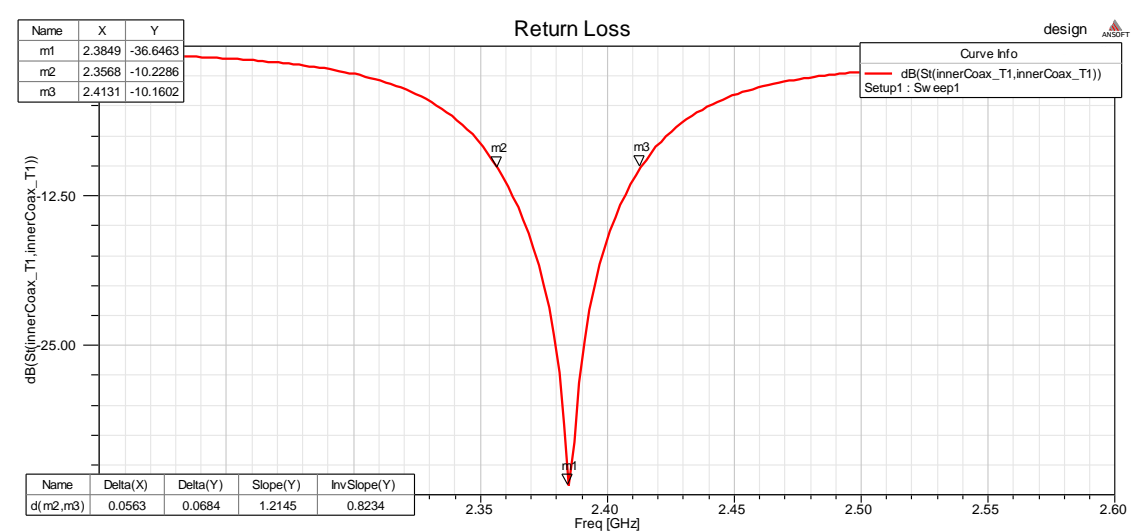

(c)

Gambar 6. Karakteristik Antena Patch Lingkaran dengan edge shorting pin dan symmetrical control pin pada variable-variable optimum : (a) pola radiasi 3D, (b) pola radiasi 2D, (c) return loss 
Realisasi antena patch lingkaran dengan edge shorting pin dan symmetrical control pin bisa dilihat pada Gambar 7 dengan radius patch $34.147 \mathrm{~mm}$, radius garis melingkar dari symmetrical control pin 18,802 mm, substrat FR4 Epoxy dengan ketebalan 1,6 mm, serta kombinasi switch 000000100011100010001000 dengan radius shorting pin 0,7 mm.

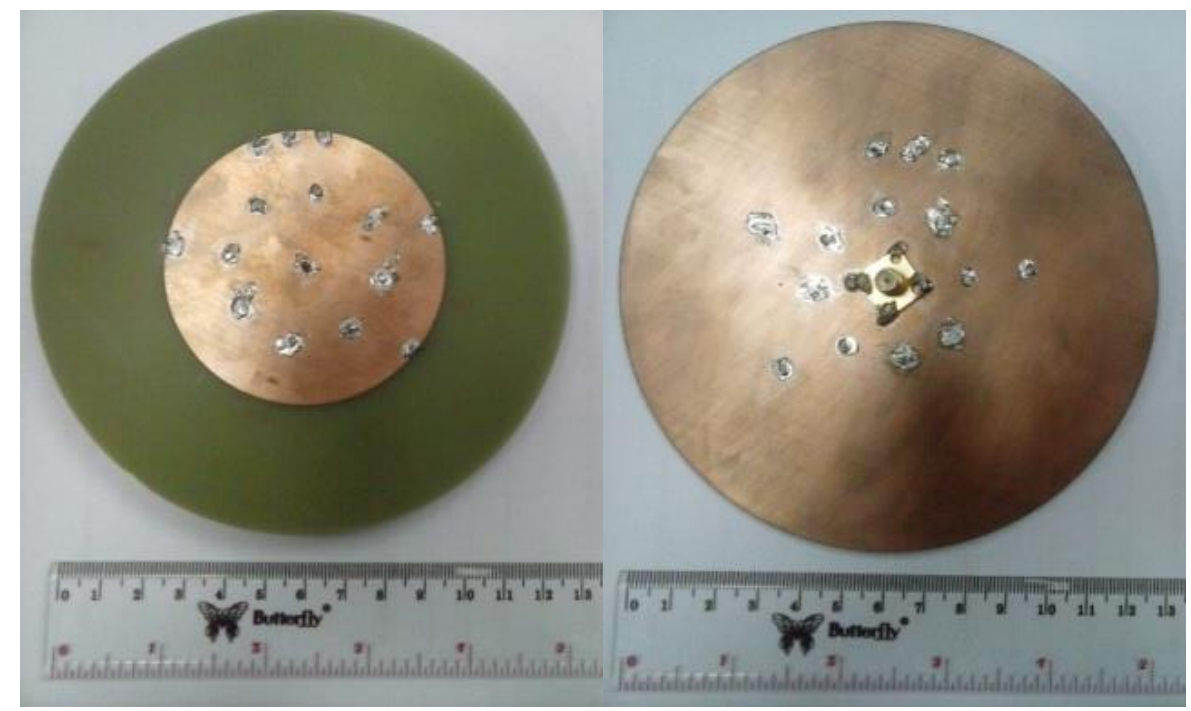

(a)

(b)

Gambar 7. Hasil Fabrikasi Antena Patch Lingkaran dengan edge shorting pin dan symmetrical control pin, (a) Tampak Depan, (b) Tampak Belakang

Gambar 9 Menunjukkan grafik perbandingan nilai Return loss antara simulasi dan pengukuran. Sedangkan pada Gambar 10 menunjukkan perbandingan pola radiasi antara simulasi dan pengukuran. Dari gambar terlihat bahwa hasil simulasi sedikit berbeda dengan pengukuran. Hal ini dikarenakan lingkungan pengukuran yang tidak ideal.

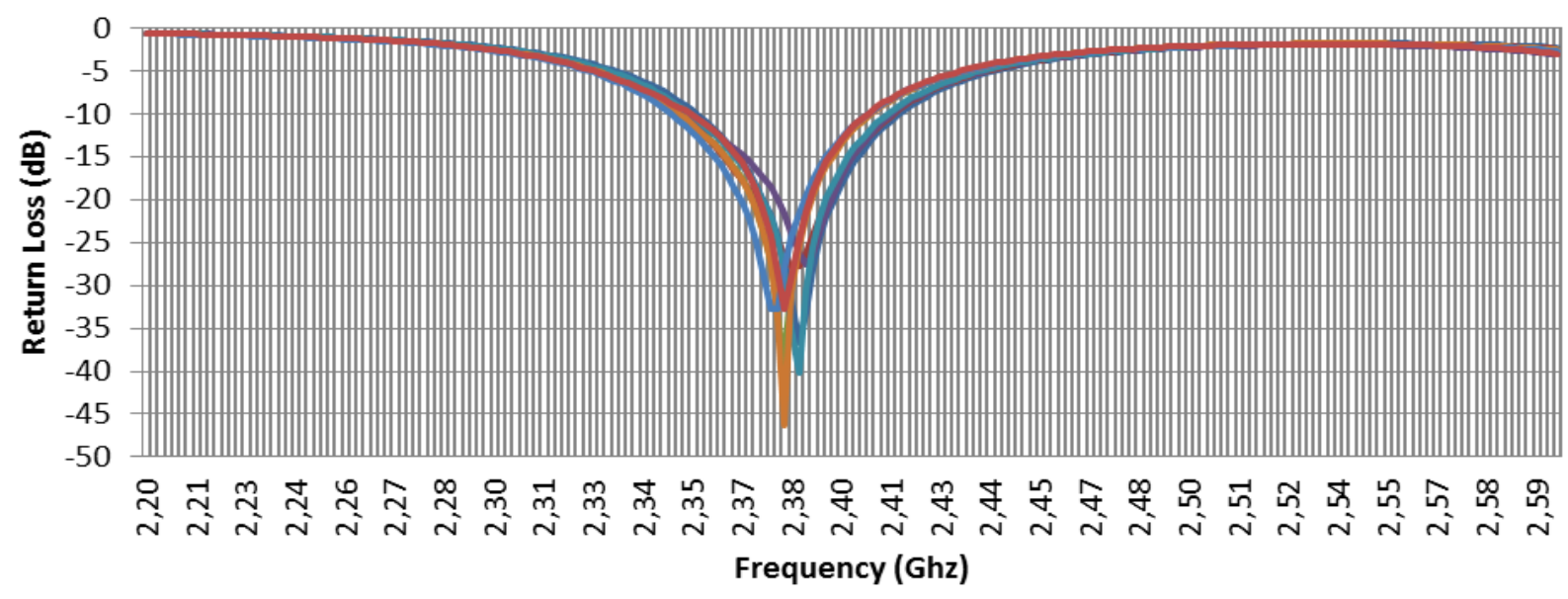

Gambar 8. Return loss pada Antena Patch Lingkaran dengan edge shorting pin dan symmetrical control pin pada 8 state 
Optimasi Kombinasi Switch Pada Pattern Reconfigurable Circular Patch Antenna Menggunakan Edge Shorting Pin Dan Symmetrical Control Pin

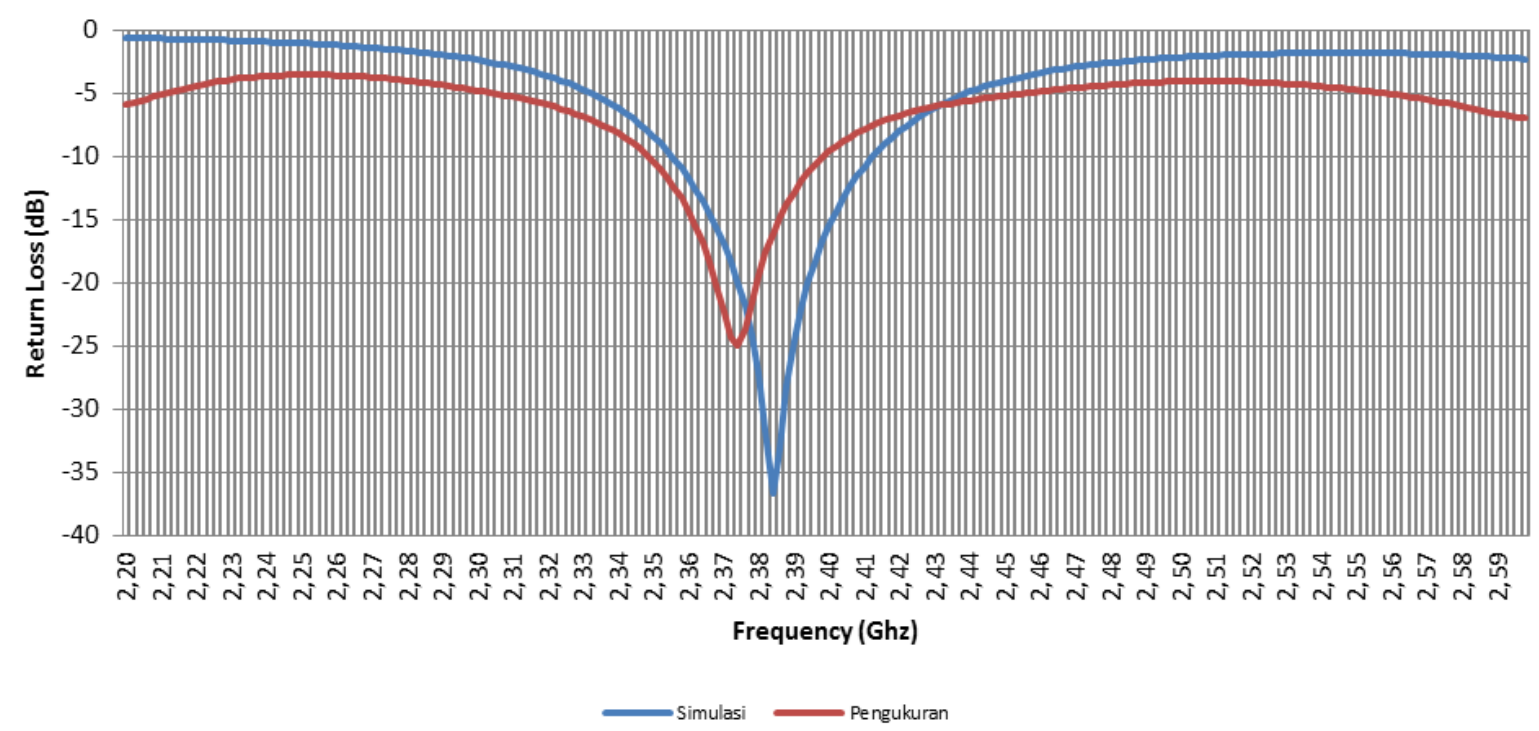

Gambar 9. Grafik Perbandingan Return loss pada Antena Patch Lingkaran dengan edge shorting pin dan symmetrical control pin

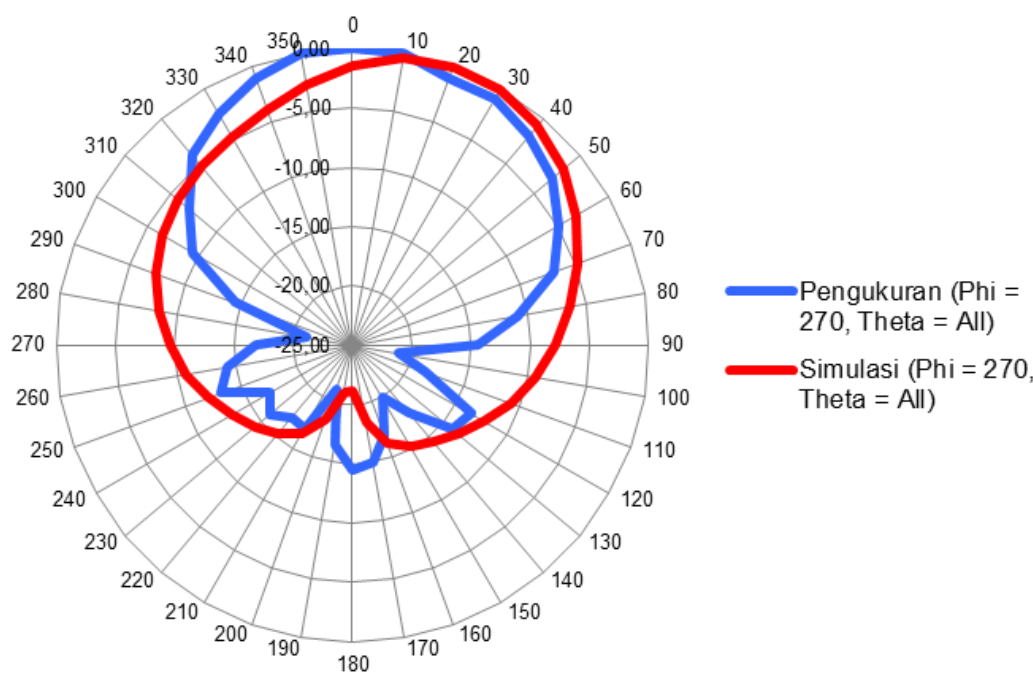

Gambar 10. Perbandingan Pola Radiasi pada Antena Patch Lingkaran dengan edge shorting pin dan symmetrical control pin 
Table Error! No text of specified style in document.. Pola radiasi azimut pada Antena Patch Lingkaran dengan edge shorting pin dan symmetrical control pin pada 8 state

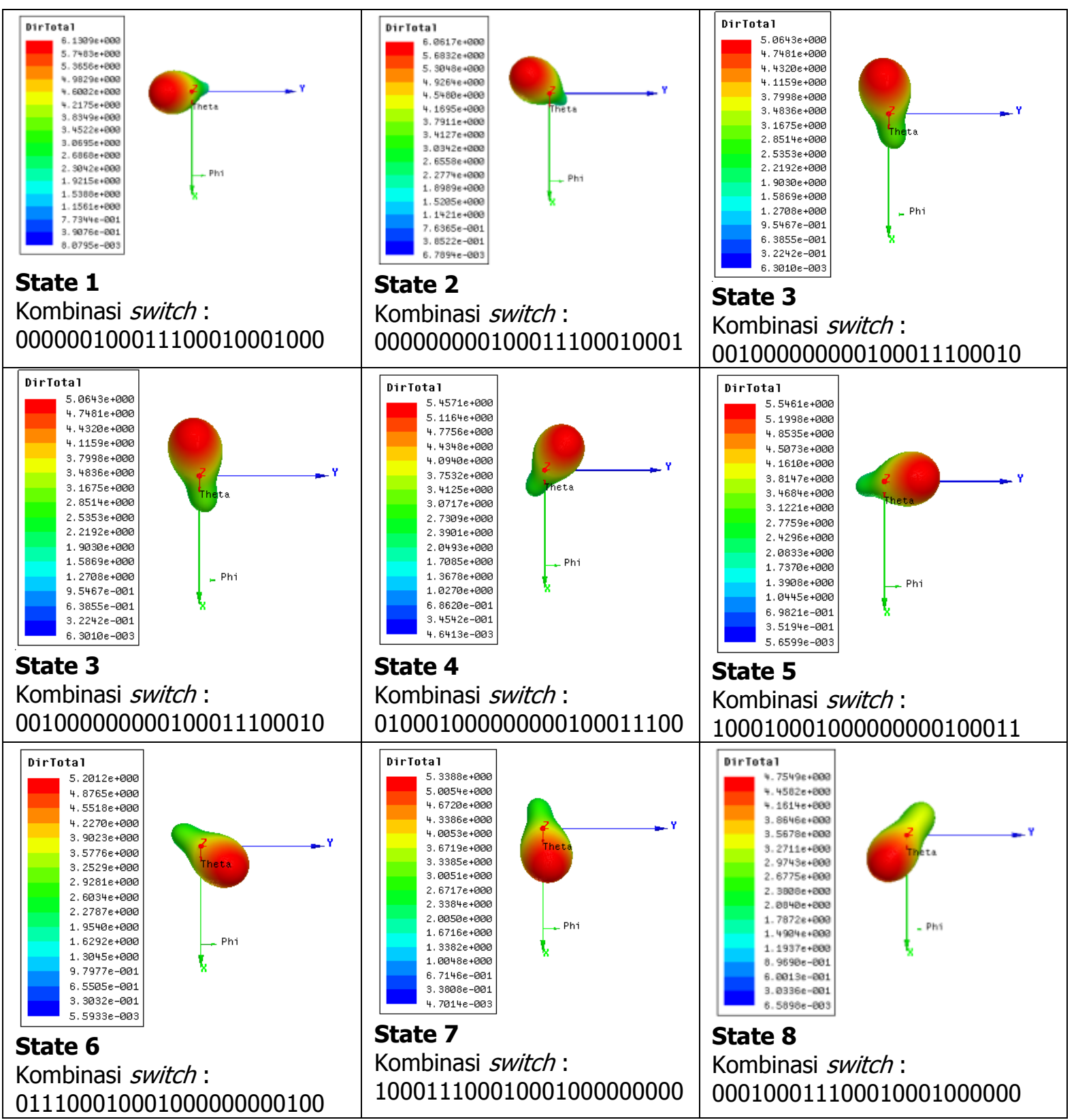

\section{KESIMPULAN}

Sebuah metode baru dalam mendesain pattern reconfigurable antenna telah diteliti. Antena yang diteliti adalah antena patch lingkaran yang diintegrasikan shorting pin-shorting pin di tepi patch serta menambahkan shorting pin melingkar pada patch nya untuk mengontrol matching impedansi. Metoda yang digunakan adalah memanfaatkan bentuk antena patch lingkaran yang simetris, sehingga dengan memutar kombinasi switch yang telah dioptimasi maka didapatlah kemampuan pattern reconfigurability. Teknik optimasi yang digunakan adalah dengan menggabungkan algoritma genetika dengan Finite Element Method. 
Pola radiasi dan plot return loss menunjukkan bahwa hasil yang diperoleh dari proses optimasi sesuai dengan tujuan yang diinginkan. Hasil optimasi telah diverifikasi dengan pengukuran antena yang telah difabrikasi.

Antena patch lingkaran dengan edge shorting pin dan symmetrical control pin yang telah dioptimasi bisa bekerja pada frekuensi $2,4 \mathrm{Ghz}$ menghasilkan 8 kemungkinan arah radiasi azzimuth dengan resolusi $45^{\circ}$ dan arah elevasi $30^{\circ}$

Untuk pekerjaan selanjutnya, switch RF dan biasing network pada pattern reconfigurable antenna ini perlu dirancang dan diimplementasikan. Efisiensi dan loss akibat implementasi switch RF perlu dipertimbangkan

\section{DAFTAR RUJUKAN}

Anders G. Derneryd. (1979). Analysis of the Microstrip Disk Antenna Element. IEEE Transactions on Antennas and Propagation, vol. ap-27, no. 5

C. B. Ravipati, D. R. Jackson, and H. Xu. (2005). Center-Fed Microstrip Antennas with Shorting Vias for Miniaturization. IEEE.

C. Jung, M.Lee, G.P.Li, and F.DeFlaviis. (2006). Reconfigurable scan-beamsingle-arm spiral antenna integrated with RF MEMS switches. IEEE Trans. Antennas Propagat., vol. 54, pp. 455-463.

D.S. Linden. (1997). Automated Design and Optimization of Wire Antennas using Genetic Algorithms. Ph.D. Thesis, MIT.

F. J. Ares-Pena, J. A. Rodriguez-Gonzalez, E. Villaneuva-Lopez, and S. R. Rengarajan. (1999). Genetic algorithms in the design and optimization of antenna array patterns. IEEE Trans. Antennas Propagation, vol.47, p.506.

G. H. Huff,J.Feng,S.Zhang,andJ.T.Bernhard. (2003). A novel radiation pattern and frequency reconfigurable single Turn square spiral microstrip antenna. IEEE Microwave Wireless Comp.Lett., vol.13, pp.57-59.

G. H. Huff and J. T. Bernhard. (2004). Analysis of a radiation and frequency reconfigurable microstrip antenna. Proc. 2004 Antenna Applications Symposium, pp. 175-191.

G. H. Huff andJ.T.Bernhard. (2006). Integration of packaged RF MEMS switches with radiation pattern reconfigurable square spiral microstrip antennas. IEEE Trans. Antennas Propagat., vol. 54, pp. 464-469.

H. Choo, A. Hutani, L.C. Trintinalia, and H. Ling. (2000). Shape optimization of broadband microstrip antennas using genetic algorithm. Electronic Letters, vol. 36, no. 25, pp. 2057-2058.

H. Choo and H. Ling. (2002). Design of Multiband Microstrip Antennas Using a Genetic Algorithm", IEEE Microwave and Wireless Components Letters, vol. 12, no. 9, pp. 345-347. 
Josef Meixner, "The Radiation Pattern and Induced Current in a Circular Antenna with an Annular Slit" Electromagnetic Wave Theory Symposium

J. T. Bernhard. (2007). Reconfigurable Antennas, ed. Constantine Balanis, Morgan \& Claypool, San Rafael, CA.

Lopez, Daniel Rodrigo. (2010). Time Reconfigurable Pixelled Antennas. Master Thesis, Universitat Polit`ecnica de Catalunya, Barcelona.

L. C. Shen, S. A. Long, M. R. Allerding, And M. D. Walton. (1997). Resonant Frequency of a Circular Disc, Printed Circuit Antenna. IEEE Transactions On Antennas And Propagation.

M. Ali, A. T. M. Sayem, and V. K. Kunda. (2007). A reconfigurable stacked microstrip patch antenna for satellite and terrestrial links. IEEE Trans. Vehicular Tech., vol. 56, no. 2, pp 426435.

N. Herscovici, M. F. Osorio, and C. Peixeiro. (2001). Minimization of a rectangular patch using genetic algorithms," in Proc. IEEE Antennas and Propagation Int. Symp., vol. 4, Boston, MA, 34-37.

O. Ozgun, S. Mutlu, M. I. Askun, and L. Alatan. (2003). Design of dual frequency probe-fed microstrip antennas with genetic optimization algorithm. IEEE Transactions on Antennas and Propagation, vol. 51, no. 8, pp. 1947-1954.

Rajanish and T. S. Vedavathy. (1999). Resonant Frequency Of Higher Order Modes For Circular Microstrip Antennas. IEEE.

Ramesh Garg, Prakash Bhatia, Inder Bahl and Apisak Ittipiboon. (2001). Microstrip Antenna Design Handbook. Artech House, Inc.

S.-H.Chen, J.-S.Row, and K.-L.Wong. (2007). Reconfigurable square-ring patch antenna with pattern diversity. IEEE Trans. Antennas Prop., vol. 55, pp. 472-475.

Zhi Ning Chen and Michael Yan Wah Chia. (2003). Center-Fed Microstrip Patch Antenna. IEEE Transactions On Antennas And Propagation, Vol. 51, No. 3.

Zhang Jiajie, Wang Anguo, Wang Peng. (2008). A Survey on Reconfigurable Antennas. IEEE. 